) Gi rask respons på artikler gjennom artikkelens kommentarfelt på tidsskriftet.no. Respons som er postet innen én måned etter at artikkelen er publisert, vurderes for publisering som Brev til redaktøren i papirutgaven.

Redaksjonen forbeholder seg retten til å foreta redaksjonelle endringer.

Forfattere av vitenskapelige artikler har tilsvarsrett, jf. Vancouver-gruppens regler.

\section{Forskning for fremtidige vaksineråd}

I Tidsskriftet nr. 15/2012 tar Elling Ulvestad opp en viktig problemstilling som vi også har vært opptatt av - nemlig om man bør fortsette å tilby vaksine til befolkningen når de første fasene av epidemien ser ut til å bli mildere enn fryktet (1). I ettertid er det lett å konkludere med at den danske strategien med bare å vaksinere risikogruppene var like effektiv som den norske, målt i antall dødsfall det første året. Det er imidlertid viktig å huske at en pandemi består av flere bølger og at det endelige resultatet av en vaksinasjon først kan bedømmes når man har gjennomgått alle bølgene. I vårt land hadde vi praktisk talt ingen dødsfall av dette pandemiviruset etter det første året, mens det $\mathrm{i}$ land der man vaksinerte få innbyggere, har vært flere titall dødsfall det påfølgende året. Tall fra Skottland, som har den best sammenliknbare statistikken, kan tyde på at det $\mathrm{i}$ land med få vaksinerte i de første fasene av pandemien, totalt sett har dødd omtrent dobbelt så mange som i Norge.

Det er også viktig å ha med seg at beslutningene om vaksinasjonsstrategi må gjøres på et tidspunkt hvor vi ikke kjenner det endelige forløpet av pandemien. Ulvestad har rett $\mathrm{i}$ at vi ganske raskt konkluderte med at pandemien mest sannsynlig ville bli langt mildere enn det verstefallsscenarioet som pandemiplanen hadde tatt høyde for. Spørsmålet var om vi kunne stole så mye på disse antakelsene at det var riktig å nedskalere vaksinasjonsplanene. Ettertiden har vist at viruset ikke endret karakter underveis, slik det gjorde under spanskesyken. Men var det riktig på det tidspunktet å la være å beskytte befolkningen mot den risikoen når vi hadde muligheten til å tilby vaksine?

Beredskapstiltak vil nesten alltid vise seg å være unødvendig sterke. Det må de være hvis vi skal kunne beskytte oss mot «tusenårsbølgen». Men det kan godt være at vi med den kunnskapen vi nå har om en helt uventet bivirkning av vaksinen, vil vurdere risikobildet annerledes. Derfor vil de spørsmålene Ulvestad tar opp, bli vurdert nøye når vi nå sammen med Helsedirektoratet skal bistå Helse- og omsorgsdepartementet med å revidere landets beredskapsplan mot fremtidige pandemier. De forskningsprosjektene vi nå har satt i gang, har ikke hatt som formål å evaluere beslutningsprosessene i den pandemien som har vært, for det har allerede vært tatt grundig opp i alle de evalueringene som har vært gjennomført. Våre forskningsprosjekter har først og fremst hatt som mål å gi oss den medisinskfaglige kunnskapen vi vil trenge når vi en gang i fremtiden på nytt skal gi helsemyndighetene og befolkningen råd om vaksinasjon mot pandemivirus.

\section{Geir Stene-Larsen}

geir.stene-larsen@hod.dep.no

Geir Stene-Larsen (f. 1955) har vært direktør i Nasjonalt folkehelseinstitutt. Ingen oppgitte interessekonflikter.

\footnotetext{
Litteratur

1. Ulvestad E. Vaksinasjonsforskning på tomgang. Tidsskr Nor Legeforen 2012; 132: 1730
}

\section{E. Ulvestad svarer:}

At Norge trenger mer «forskning for fremtidige vaksineråd» synes åpenbart. Men det er ikke like åpenbart at det er medisinskfaglig forskning vi trenger mer av. I hvert fall var det ikke fravær av medisinskfaglig kunnskap som gjorde at vi i Norge valgte en annen vaksinasjonsstrategi enn Danmark høsten 2009. Begge lands myndigheter hadde tilgang til de samme observasjoner og det samme teoretiske rammeverket. Forskjellen var at der danske myndigheter valgte å forholde seg til observasjonene og oppdaterte teoretiske modeller, valgte norske myndigheter å forholde seg til scenarioer bygd på erfaringer gjort under spanskesyken i 1918/19.

Under svineinfluensaen ble Norge rammet relativt sent i forløpet. Vi fikk dermed rikelig tilgang til data som beskrev influensaens virulens og spredningsmønster. Denne kunnskapen, som overhodet ikke stemte overens med prediksjoner gitt av spanskesykescenarioet, ble av en eller annen grunn oversett. Når Stene-Larsen i sitt innlegg stiller spørsmålet om «vi kunne stole så mye på disse antakelsene at det var riktig å nedskalere vaksinasjonsplanene», sier han samtidig at kunnskapen helsemyndighetene fikk fra observasjonene ble vektet lavt. Nettopp for å ta rede på hva det var ved planleggingssituasjonen som tillot at data kunne tilsidesettes på denne måten, trenger vi en gransking. For det var denne tilsidesettingen som førte til at helsemyndighetene fikk sin særegne virkelighetsforståelse og dermed sitt ikke-tilpassede handlingsmønster. Forskning for å vinne mer medisinskfaglig kunnskap, slik SteneLarsen tar til orde for, vil være null verdt dersom vi holder oss med beslutningstakere som velger å overse kunnskapen.

Stene-Larsen mener en undersøkelse av beslutningsprosessen er unødvendig fordi disse spørsmålene allerede har vært «tatt grundig opp». Men dersom han med dette utsagnet sikter til myndighetenes egen evaluering, utført av Direktoratet for samfunnssikkerhet og beredskap, har han misoppfattet rapportens budskap. I den rapporten uttrykte direktoratet med klare ord at de ikke hadde «grunnlag for å ta stilling til om rådet om massevaksinering var riktig eller galt» (1). Dessverre brukes rapporten nå ukritisk, både av helsemyndigheter og politikere, som «autorisert» dokumentasjon på at helsemyndighetene ikke hadde noen alternativer til massevaksinasjon høsten 2009.

$\AA$ avfeie et begrunnet ønske om forskningsbasert avklaring av hendelsene som ledet frem til beslutningen om massevaksinasjon, med henvisning til at forholdene allerede er godt nok undersøkt, er et retorisk grep som neppe tjener vårt felles medisinskfaglige anliggende: optimal håndtering av neste pandemi.

\section{Elling Ulvestad \\ elling.ulvestad@helse-bergen.no}

Elling Ulvestad (f. 1958) er spesialist i immunologi og transfusjonsmedisin. Han er avdelingssjef for Mikrobiologisk avdeling, Haukeland universitetssykehus, og professor ved Gades institutt, Universitetet i Bergen. Forfatter har fylt ut ICMJE-skjemaet og oppgir følgende interessekonflikter: Han har vært rettsoppnevnt sakkyndig (september 2011) for rettssak i Oslo tingrett i forbindelse med bivirkninger av meningokokkvaksine.

\section{Litteratur}

1. Ny influensa A (H1N1) 2009 - gjennomgang av erfaringene i Norge. Tønsberg: Direktoratet for samfunnssikkerhet og beredskap, 2010: 15. www.dsbinfo.no/ DSBno/2010/Rapport/Pandemirapport/ (19.9.2012) 